\title{
RANCANG BANGUN APLIKASI HYBRID KONDISI JALAN DAN FASILITAS KELENGKAPAN JALAN DI KOTA MATARAM
}

\author{
(Design of Hybrid Application of Roads and Road Fittings Facilities Conditions in City \\ of Mataram)
}

\author{
Puspita Asri Nurmalasari", Nadiyasari Agitha, Ahmad Zafrullah Mardiansyah \\ Program Studi Teknik Informatika, Fakultas Teknik, Universitas Mataram \\ JI. Majapahit 62, Mataram, Lombok NTB, INDONESIA \\ Email: puspita087@gmail.com, nadiya @unram.ac.id, zaf@unram.ac.id
}

\begin{abstract}
Hybrid Application of Roads and Road Fittings Facilities Conditions in the City of Mataram is an application consisting of web applications and mobile applications. The web application is used by Dinas Pekerjaan Umum dan Penataan Ruang of mataram city and Dinas Perhubungan of mataram city to manage condition data from city roads and also road fittings facilities in the city of Mataram and to receive complaints of damage from the public. While the mobile application is used by the people of the city of Mataram to see the condition of the road and road fittings facilities based on data from the department and the public can also make complaints about damage from roads and road facilities. System testing using the Black Box method and Mean Opinion Score (MOS) testing. MOS test results indicate that the average rating of respondents from Dinas Pekerjaan Umum dan Penataan Ruang of Mataram City stated strongly agree and agree were $66.67 \%$ and $33.33 \%$. The average rating of respondents from Dinas Perhubungan of Mataram City stated strongly agree and agree were $58,33 \%$ and $41,67 \%$. The average rating of respondents from the community stated strongly agree and agree were $52,50 \%$ and $44,17 \%$. Therefore, this research concluded that this system is eligible to use.
\end{abstract}

Keywords: Hybrid Application, Road, Road Fittings Facilities, Complaint, Mean Opinion Score.

*Penulis Korespondensi

\section{Pendahuluan}

Jalan merupakan prasarana transportasi darat yang meliputi segala bagian jalan, termasuk bangunan pelengkap dan perlengkapannya yang diperuntukan bagi lalu lintas. Sedangkan, perlengkapan jalan adalah sarana yang dimaksudkan untuk keselamatan, keamanan, ketertiban, dan kelancaran lalu lintas serta kemudahan bagi pengguna jalan dalam lalu lintas[1]. Jalan yang terpasang perlengkapan jalan bertujuan untuk mencegah tindakan-tindakan yang membahayakan keselamatan lalu lintas, sehingga sangat penting bagi lembaga pemerintah terkait bekerja sama dengan masyarakat pengguna jalan maupun penduduk sekitar jalan untuk memperhatikan kondisi jalan dan perlengkapannya.

Jalan dan kelengkapan jalan di Kota Mataram ditangani oleh beberapa lembaga pemerintah yang berbeda. Untuk memantau kondisi ruas jalan dengan status jalan kota dilakukan oleh Dinas Pekerjaan Umum dan Penataan Ruang Kota Mataram sedangkan untuk beberapa fasilitas kelengkapan jalan di kota Mataram ini ditangani oleh Dinas Perhubungan Kota Mataram. Dari kedua lembaga tersebut dalam pengelolaan datanya masih belum memanfaatkan sebuah sistem yang saling berintegrasi, dimana data-data dalam setahun tersimpan dalam sebuah file berformat document. Hal tersebut dapat mengakibatkan kemungkinan kehilangan data yang sangat besar dan juga kesulitan dalam menganalisa kesimpulan data untuk membuat laporan tahunan. Begitu juga dengan informasi kegiatan perbaikan/pembangunan jalan ataupun fasilitas kelengkapan jalan yang sedang dilakukan sering ditemukan oleh masyarakat hanya pada akun media sosial milik dinas atau melalui media berita. Maka diperlukan suatu sistem yang terintegrasi untuk mengelola data yang banyak dari setiap ruas jalan dan fasilitas kelengkapan jalan yang terpasang, serta mengelola pengumuman perbaikan/pembangunan yang dilakukan dinas sehingga menjadi informasi yang dapat diakses oleh masyarakat dan juga masyarakat dapat melakukan pengaduan kerusakan yang terkirim langsung ke dinas yang menangani jalan maupun menangani fasilitas kelengkapan jalan.

Seiring dengan berkembangnya teknologi informasi, banyak teknologi baru yang muncul seperti 
halnya teknologi mobile berbasis android yang memudahkan pengguna dalam mengakses informasi yang dibutuhkan dimana saja dan kapan saja. Selain itu, terdapat hybrid application sebagai salah satu jenis aplikasi mobile yang merupakan aplikasi web yang ditransformasikan menjadi kode native pada platform mobile. Jenis aplikasi mobile tersebut dipasang langsung pada perangkat mobile namun menjalankannya membutuhkan koneksi internet, serta memiliki kelebihan dimana aplikasi dapat dijalankan pada platform yang berbeda-beda. Selain itu, terdapat perkembangan suatu Sistem Informasi Geografis (SIG) yang dapat didefinisikan sebagai sistem komputer yang digunakan untuk memanipulasi, menganalisis, dan menampilkan data-data yang berhubungan dengan posisi-posisi di permukaan bumi.

Berdasarkan uraian di atas, maka dalam penelitian ini akan dirancang dan dibangun aplikasi hybrid untuk memenuhi kebutuhan akan kecepatan dan keakuratan dalam melakukan pendataan, penyampaian ataupun untuk mendapatkan informasi terkait kondisi jalan dan fasilitas kelengkapan jalan yang berada di Kota Mataram. Pada aplikasi yang akan digunakan oleh admin, berupa aplikasi web dengan fitur mengelola data jalan dan fasilitas kelengkapan, pengumuman perencanaan pemasangan atau perbaikan yang akan dilakukan, melihat pengaduan-pengaduan kerusakan, melakukan feedback dari pengaduan yang diterima, dan melihat laporan tahunan berupa tabel dan grafik untuk pengaduan kerusakan, kondisi jalan, dan pengadaan fasilitas kelengkapan jalan. Aplikasi yang akan digunakan oleh user (masyarakat Kota Mataram), berupa aplikasi mobile dengan fitur melihat kondisi jalan dan fasilitas kelengkapan jalan yang ada di Kota Mataram, melihat pengumuman pembangunan atau perbaikan akan dilakukan, dan melihat pengaduan yang telah dilakukan oleh user lain. Fitur aplikasi lainnya yaitu untuk mengirim pengaduan berdasarkan kategori kerusakan jalan ataupun kerusakan kelengkapan jalan, disertai dengan mengirimkan lokasi keberadaan fasilitas yang rusak dan bukti berupa gambar.

\section{TinjauAn PUStaka}

Nastiar [2] merancang dan membangun sistem pelaporan kerusakan jalan berbasis web dan mobile, laporan dalam bentuk foto langsung dapat dikirim ke website dan petugas dapat menampilkan langsung laporan yang telah diterima kepada kepala bidang Bina Marga. Sistem memudahkan dalam pengolahan data pelaporan kerusakan jalan, pemetaan laporan menggunakan maps tersimpan dengan baik yang memudahkan dalam proses pencarian data. Adapun kekurangan dalam penelitian ini adalah pengguna aplikasi hanya dapat melihat pelaporan kerusakan jalan yang pernah dilakukannya tapi tidak dapat melihat kerusakan jalan yang dilaporkan oleh pengguna lainnya.

Sihombing [3] merancang sistem informasi pelaporan masyarakat dengan dua antarmuka yang responsive, dimana dapat dibuka melalui dekstop web browser maupun mobile web browser. Sistem dapat menampilkan informasi pemetaan kerusakan jalan yang ada di Pontianak menggunakan Google Maps API, menampilkan secara real time koordinat pengguna dari perangkat GPS yang ada pada smartphone pengguna saat melakukan pelaporan kerusakan, dan administrator dapat menerima laporan kerusakan dari masyarakat berupa foto dan data kerusakan jalan. Adapun kekurangan dalam penelitian ini adalah sistem hanya dimanfaatkan untuk melakukan pengaduan kerusakan jalan saja, tidak ada informasi yang diberikan tentang perbaikan jalan yang akan dilakukan. Selain itu, karena masyarakat melakukan pengaduan kerusakan tanpa melalui login dahulu maka menyulitkan untuk mencari pengaduan yang pernah dilakukan.

Pramuji [4] merancang aplikasi android menggunakan bahasa pemrograman java, aplikasi ini dapat melakukan pengaduan laporan kerusakan jalan yang berada di wilayah Sleman secara real, menampilkan informasi dari dinas Pekerja Umum dan Perumahan tentang jalan seperti informasi perbaikan jalan yang dilakukan atau sedang dilakukan oleh dinas Pekerja Umum dan Perumahan. Aplikasi dapat menghasilkan laporan berupa grafik tingkat kerusakan jalan per kecamatan di wilayah Sleman. Adapun kekurangan dalam penelitian ini, dimana aplikasi web yang digunakan oleh admin yang hanya mengelola data kerusakan jalan yang berasal dari laporan yang telah dilakukan masyarakat, begitupun informasi umum yang diberikan ke masyarakat merupakan informasi yang merupakan tanggapan admin dari laporan kerusakan yang telah dilakukan masyarakat.

Berdasarkan tinjauan di atas, maka pembahasan pada penelitian ini adalah bagaimana merancang serta membangun aplikasi hybrid kondisi jalan dan fasilitas kelengkapan jalan di Kota Mataram. Perancangan memiliki beberapa kesamaan dan kelebihan dari penelitian sebelumnya. Sistem yang dirancang berbasis mobile dan web yang memanfaatkan teknologi Google Maps. Pengguna sistem terdiri dari masyarakat kota Mataram sebagai pengguna sistem berbasis mobile, serta dinas yang menangani jalan dan dinas yang 
menangani fasilitas kelengkapan jalan sebagai pengguna sistem berbasis web. Sistem berbasis web memiliki fitur mengelola data jalan dan mengelola data fasilitas kelengkapan jalan yang ada di Kota Mataram, memberikan informasi perbaikan atau pembangunan yang memungkinkan dapat mengganggu kenyamanan pengguna jalan dan masyarakat sekitar, fitur melihat pengaduan kerusakan yang dilakukan masyarakat kota, dan melihat laporan tahunan yang berdasarkan pengaduan kerusakan yang dilakukan masyarakat dan juga kondisi dari jalan dan fasilitas kelengkapan jalan sesuai dari pendataan yang telah dilakukan. Untuk sistem berbasis mobile memiliki fitur untuk melakukan pengaduan kerusakan disertai dengan bukti berupa foto dan koordinat kerusakan, fitur melihat pengaduan yang dilakukan oleh pengguna aplikasi mobile lain, fitur melihat pengumuman perbaikan atau pembangunan yang dilakukan, fitur melihat fasilitas kelengkapan jalan yang terpasang.

\section{Metode Penelitian}

Model waterfall merupakan model yang melakukan pendekatan secara sistematis dan urut mulai dari level kebutuhan sistem lalu menuju ke tahap analisi, desain, coding, testing dan maintenance[5]. Metode pembuatan aplikasi hybrid kondisi jalan dan fasilitas kelengkapan jalan di kota Mataram terdiri dari bebrapa tahapan yang dapat dilihat pada Gambar 1.

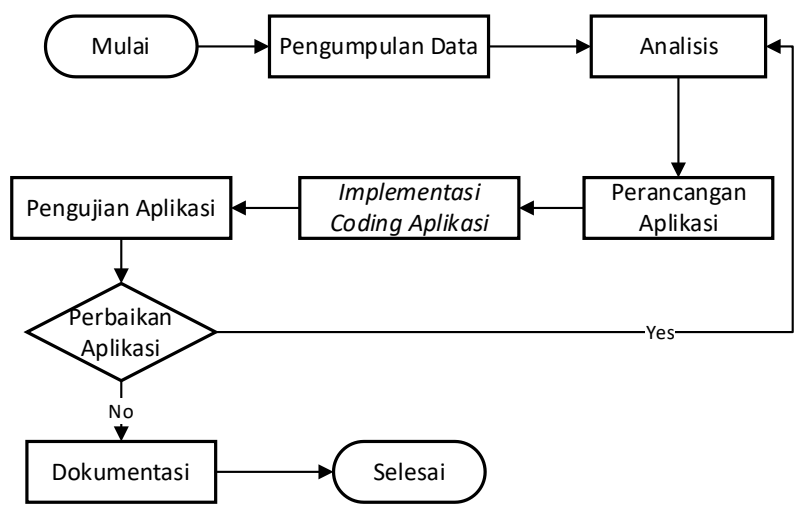

Gambar 1. Metode pembuatan sistem

\subsection{Pengumpulan Data}

Pada tahap pengumuplan data yang dibutuhkan untuk merancang dan membangun sistem, peneliti menggunakan Teknik pengumpulan data dengan cara sebagai berikut:

\subsubsection{Studi Literatur}

Tahap studi literatur dilakukan dengan mempelajari dan memahami literatur seperti bukubuku, jurnal, serta mengakses beberapa situs terkait dengan penelitian yang dilakukan sehingga dapat menjadi sebagai pembanding dalam pembuatan aplikasi, dan kekurangan yang terdapat pada penelitian terkait dapat dijadikan sebagai masukan dalam aplikasi yang akan dibuat.

\subsubsection{Observasi}

Tahap observasi dilakukan di Dinas Perhubungan Kota Mataram dan juga Dinas Pekerjaan Umum dan Penataan Ruang Kota Mataram, dimana hal tersebut bertujuan untuk mengetahui sistem yang sedang berjalan saat ini dan untuk mendapatkan data-data lengkap tentang informasi fasilitas kelengkapan jalan yang terpasang dan jalan kota di Kota Mataram, beserta bentuk laporan tahunan yang dilakukan oleh lembaga terkait jalan maupun kelengkapan jalan.

\subsection{Analisis}

Tahap analisis dilakukan dalam penelitian ini dibagi menjadi beberapa jenis analisis yaitu analisis sistem yang sedang berjalan dan analisis sistem yang akan dibangun.

\subsubsection{Analisis sistem yang sedang berjalan}

Pada tahap ini dilakukan analisis sistem proses pengelolaan data serta laporan yang dilakukan Dinas Pekerjaan Umum dan Penataan Ruang Kota Mataram untuk masalah jalan dan Dinas Perhubungan Kota Mataram untuk masalah fasilitas kelengkapan jalan. Setiap tahun Bina Marga melakukan pendataan ulang terhadap ruas jalan untuk melihat perubahan panjang dan presentasi dari setiap kategori kondisi jalan. Begitu pula pada Dinas Perhubungan, setiap tahunnya membuat pembukuan yang berisi pendataan pengadaan setiap kategori fasilitas kelengkapan yang dilakukan pada tahun tersebut dan laporan berupa tabel dan grafik peningkatan jumlah fasilitas kelengkapan yang terpasang setiap tahunnya. Proses pendataan yang dilakukan untuk jalan maupun fasilitas kelengkapan jalan belum memanfaatkan sebuah sistem yang saling berintegrasi, dimana data-data dalam setahun tersimpan dalam sebuah file berformat document. Hal tersebut dapat mengakibatkan kemungkinan kehilangan data yang sangat besar dan juga kesulitan dalam menganalisis kesimpulan data untuk membuat laporan tahunan.

\subsubsection{Analisis sistem yang akan dibuat}

Pada tahap ini dilakukan analisis sistem yang akan dibuat yaitu sistem pengolahan data yang memudahkan pemerintah dan masyarakat Kota 
Mataram untuk memantau kondisi jalan dan fasilitas kelengkapan jalan yang ada di Kota Mataram.

Pada sistem yang akan digunakan oleh bidang pada Dinas Pekerjaan Umum dan Penataan Ruang Kota Mataram dan Dinas Perhubungan Kota Mataram sebagai admin untuk melakukan pendataan juga memiliki fitur laporan, dimana fitur ini untuk melihat perkembangan statistik dari kondisi jalan maupun kelengkapan jalan berdasarkan masukan yang dilakukan oleh admin serta berdasarkan pengaduan kerusakan yang dilakukan masyarakat.

Pada sistem yang akan digunakan masyarakat memiliki fitur untuk melihat kondisi dan juga fitur pengaduan kerusakan jalan maupun kelengkapan jalan. Fitur melihat kondisi ini berdasarkan masukkan yang dilakukan oleh admin dan pengaduan kerusakan yang telah dilakukan masyarakat lainnya. Sedangkan untuk fitur pengaduan kerusakan, pengaduan yang dilakukan langsung terkirim ke sistem yang digunakan oleh admin yang bertanggung jawab sesuai kategori pengaduan (jalan atau kelengkapan jalan).

\subsection{Perancangan Sistem}

Pada tahap ini dilakukan perancangan aplikasi yang akan dibuat terdiri dari perancangan arsitektur aplikasi, diagram use case, class, sequence, activity, entity relationship diagram, dan desain interface.

\subsubsection{Perancangan Arsitektur Sistem}

Aplikasi yang dibuat merupakan hybrid application sehingga dapat di-install pada perangkat bergerak dengan sistem operasi android yang digunakan untuk masyarakat kota Mataram. Selain itu dibagun juga aplikasi web sebagai pelengkap hybrid application yang hanya dapat diakses oleh admin dari dinas. Perancangan arsitektur sistem menggambarkan proses aplikasi mobile dan juga aplikasi web yang terhubung dengan internet melakukan request data ke web server yang terhubung dengan database server dan juga Google Maps server. Kemudian web server yang melakukan respond data sesuai dengan yang diinginkan. Arsitektur sistem yang akan dibagun dapat dilihat pada Gambar 2.

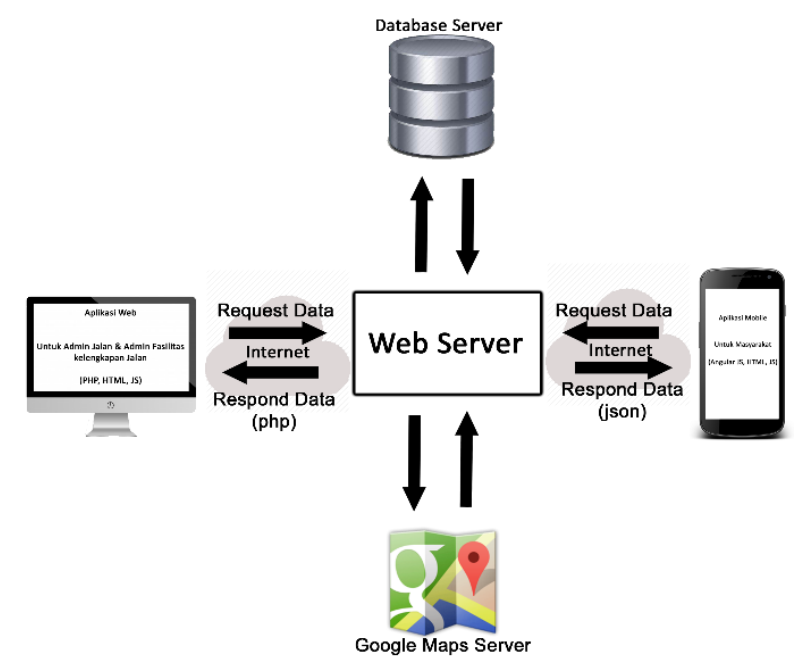

Gambar 2. Rancangan Arsitektur Sistem

\subsubsection{Perancangan usecase diagram}

Usecase diagram mendiskripsikan interaksi antara para pengguna sistem atau aktor dengan sistem itu sendiri, dengan memeberikan sebuah narasi tentang bagaimana sistem tersebut digunakan[5]. Pada sistem ini terdapat 3 aktor yaitu admin dari Dinas Pekerjaan Umum dan Penataan Ruang Kota Mataram, admin dari Dinas Perhubungan Kota Mataram yang menggunakan aplikasi web, serta masyarakat kota Mataram yang akan menggunakan aplikasi mobile. Usecase diagram memudahkan pengguna mengetahui proses-proses yang dapat dilakukan di dalam sistem ini. Perancangan usecase diagram dapat dilihat pada Gambar 3.

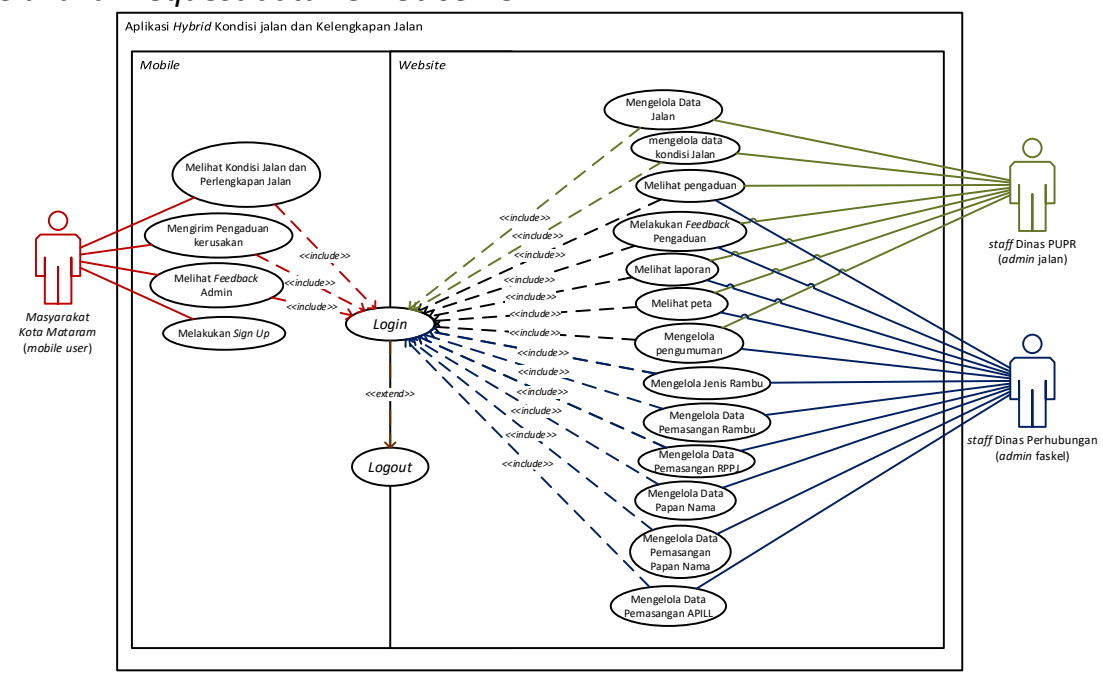

http://jtika.if.unram.ac.id/index.php/JTIKA/ 
Gambar 3. Rancangan Usecase Diagram.

\subsubsection{Perancangan Database}

Perancangan selanjutnya merupakan perancangan untuk databases atau perancangan Entity Relationship Diagram (ERD). ERD merupakan suatu model yang digunakan untuk menjelaskan hubungan antar data dalam basis data dan relasi yang dimiliki. Selain itu ERD juga memodelkan struktur data, dimana untuk menggambarkannya digunakan simbol dan notasi[6]. ERD dalam sistem yang akan dibangun terdiri dari 13 notasi entitas yang saling berelasi. Perancangan database sistem dapat dilihat pada Gambar 4.

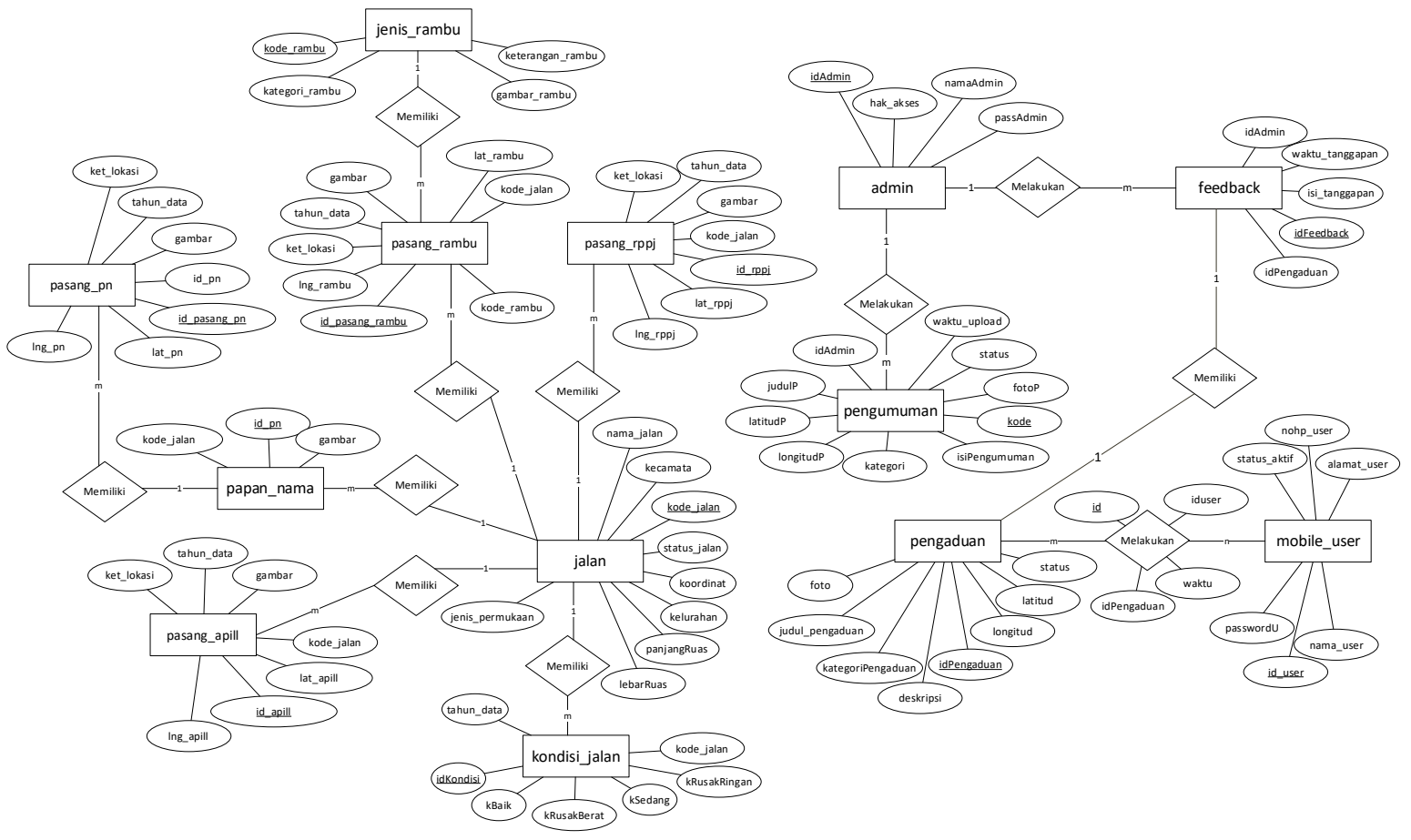

Gambar 4. Rancangan Databases Sistem

\section{HASIL DAN PEMBahasan}

Aplikasi hybrid kondisi jalan dan fasilitas kelengkapan jalan di kota Mataram terdiri dari dua buah aplikasi yaitu aplikasi web dan juga aplikasi mobile yang saling terintegrasi satu sama lainnya.

\subsection{Implementasi sistem}

Pada tahap ini dilakukan proses implementasi coding dari rancangan sistem ke dalam bentuk bahasa pemrograman. Sistem yang digunakan oleh dinas menggunakan framework Codeigniter, yang berupa framework PHP dengan model MVC (Model, View, Controller) untuk membangun website dinamis dengan menggunakan PHP[5]. Sedangkan, sistem yang digunakan oleh masyarakat kota Mataram dibangun menggunakan framework lonic yang merupakan kerangka kerja yang dibangun untuk mengembangkan aplikasi hybrid mobile dengan menggunakan teknologi web. Ionic menyediakan komponen-komponen mobile seperti button, header-footer, cards, dan lain sebagainya kemudian menyediakan css standar dan menggunakan javascript untuk menjalankan fungsi- fungsi aplikasi, untuk javascript sendiri ionic memakai teknologi angular.js [6].

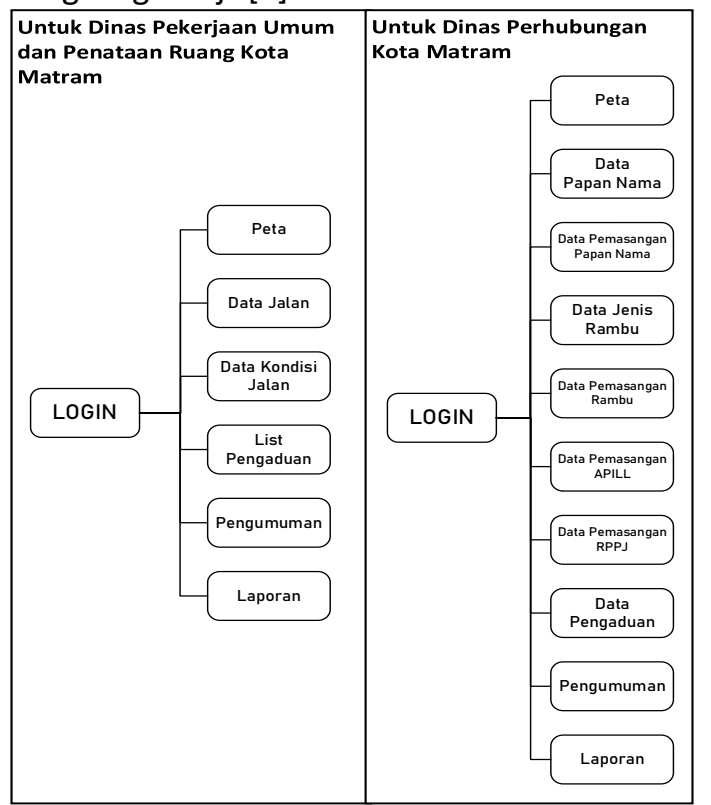

Gambar 5. Site map aplikasi web untuk admin dinas. 


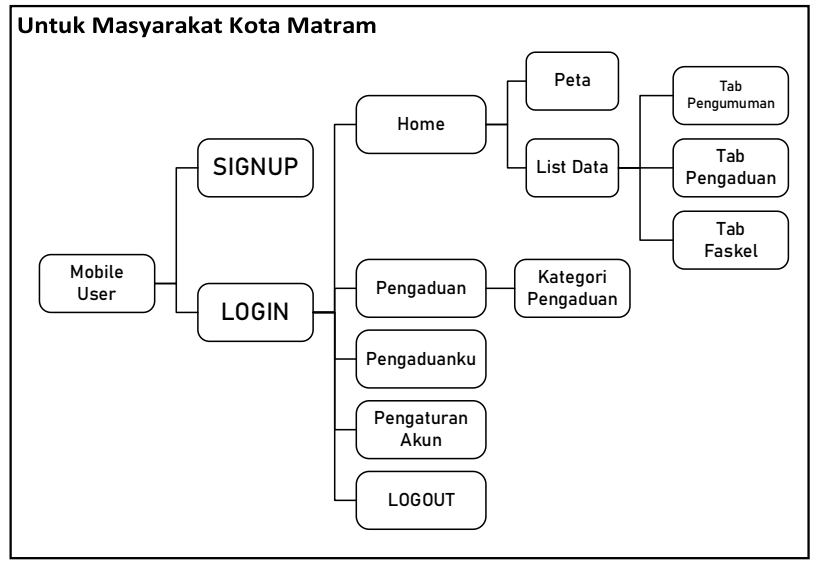

Gambar 6. Site map aplikasi mobile untuk masyarakat.

\subsubsection{Tampilan aplikasi web}

Aplikasi web digunakan oleh admin dari Dinas Pekerjaan Umum dan Penataan Ruang Kota Mataram dan juga admin dari Dinas Perhubungan Kota Mataram. Untuk kedua admin menu yang diakses ada sedikit perbedaan dikarenakan data yang diolah berbeda di tiap dinas. Menu aplikasi web yang digunakan oleh admin dari Dinas Pekerjaan Umum dan Penataan Ruang Kota Mataram memiliki menu-menu untuk mengelola data kondisi ruas jalan kota. Pada Gambar 7 dapat dilihat tampilan menu Peta yang merupakan menu yang pertama kali dimunculkan setelah berhasil login. Pada halaman menu Peta ditampilkan sebuah peta yang berpusat di Kota Mataram, dimana dalam peta ditampilkan marker posisi pengaduan kerusakan jalan, marker posisi perbaikan/pembangunan jalan, dan polyline ruas-ruas jalan kota. Kemudian pada bagian pojok kanan atas terdapat tombol dengan fungsi untuk menganti password, mengelola mobile user dan untuk logout.

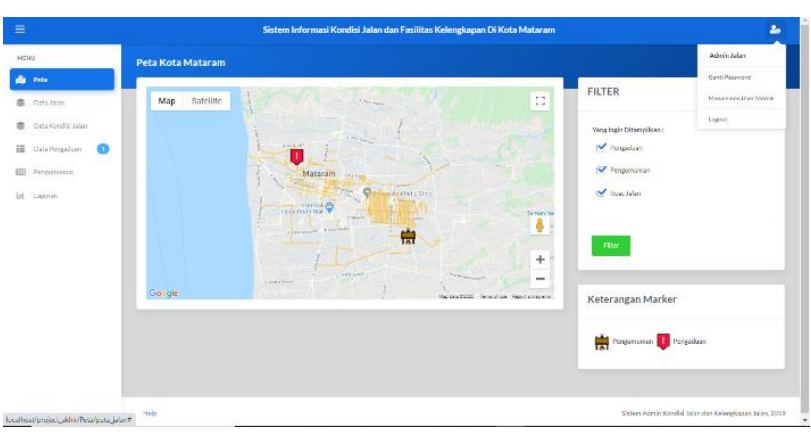

Gambar 7. Halaman menu peta untuk admin dari Dinas Pekerjaan Umum dan Penataan Ruang Kota Mataram.

Menu aplikasi web yang digunakan oleh admin dari Dinas Perhubungan Kota Mataram memiliki menu- menu untuk mengelola data pemasangan fasilitas kelengkapan jalan. Pada Gambar 8 dapat dilihat tampilan menu Peta yang merupakan menu yang pertama kali dimunculkan setelah berhasil login. Pada halaman menu Peta ditampilkan sebuah peta yang berpusat di Kota Mataram, dimana dalam peta ditampilkan marker posisi pengaduan kerusakan fasilitas, marker posisi perbaikan/pembangunan fasilitas, dan marker posisi pemasangan fasilitas kelengkapan jalan. Kemudian pada bagian pojok kanan atas terdapat tombol dengan fungsi untuk menganti password, mengelola mobile user dan untuk logout.

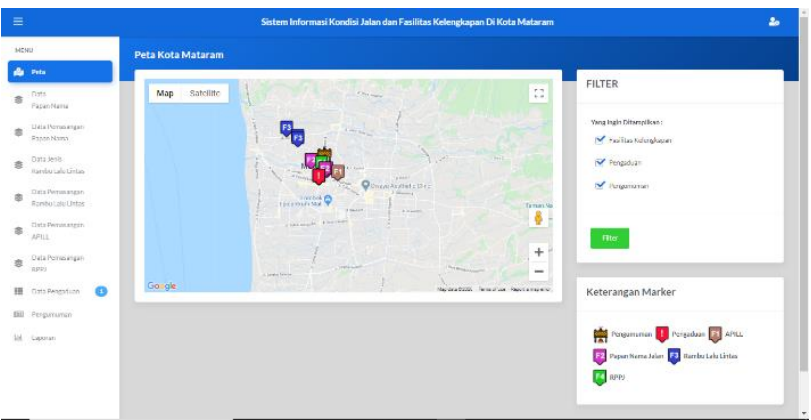

Gambar 8. Halaman menu peta untuk admin dari Dinas Perhubungan Kota Mataram

Aplikasi web yang digunakan oleh dinas memiliki menu untuk mengelola pengaduan kerusakan yang berasal dari pengaduan dari aplikasi mobile. Data pengaduan yang ditampilkan berdasarkan admin yang sedang login ke aplikasi web, apakah pengaduan kerusakan jalan atau pengaduan kerusakan fasilitas kelengkapan jalan. Data dapat dilihat detailnya kemudia admin dapat melakukan pesan tanggapan untuk pengaduan tersebut. Tampilan detail pengaduan dapat dilihat pada Gambar 9.

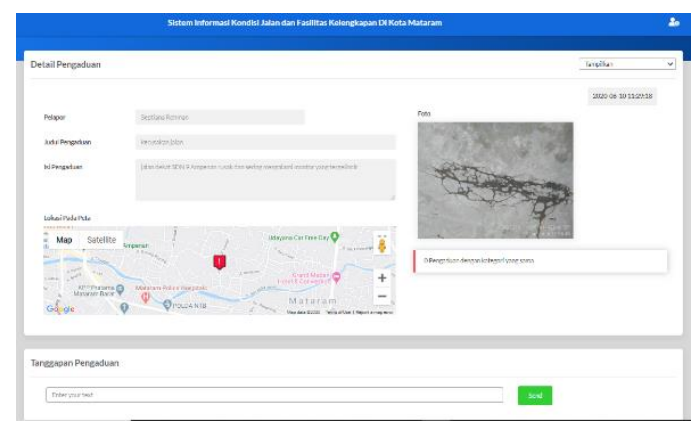

Gambar 9. Halaman detail pengaduan

Aplikasi web yang digunakan oleh dinas memiliki menu untuk mengelola pengumuman. Data pengumuman yang ditampilkan berdasarkan admin yang sedang login ke aplikasi web, apakah pengumuman jalan atau fasilitas kelengkapan jalan. Dinas dapat meng-input pengumuman perbaikan atau 
pembangunan yang dilakukan. Tampilan form pengumuman dapat dilihat pada Gambar 10.

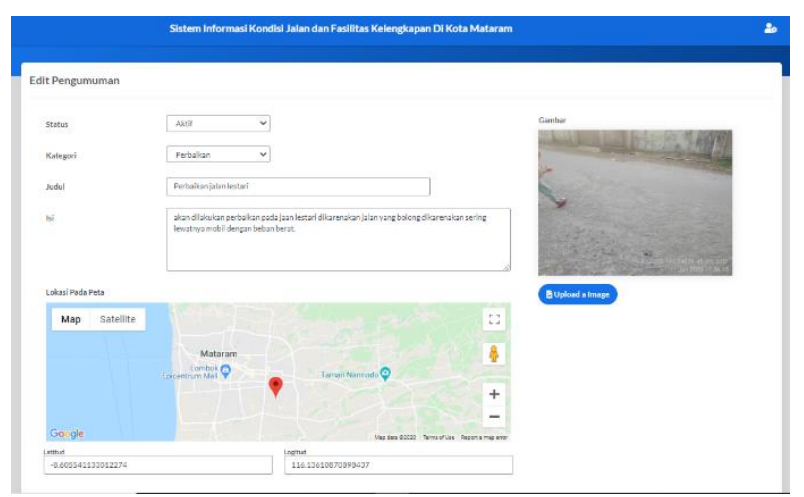

Gambar 10. Halaman form pengumuman.

\subsubsection{Tampilan aplikasi mobile}

Aplikasi mobile digunakan oleh masyarakat kota Mataram. Terdapat beberapa menu dalam aplikasi mobile ini antara lain menu home yang berisi data-data pengaduan kerusakan, pengumuman, dan fasilitas kelengkapan yang terpasang. Menu pengaduan untuk melakukan proses pengaduan kerusakan. Menu pengaduanku yang berisi pengaduan yang telah dilakukan oleh pemiliki akun. Menu pengaturan akun berisi data pemilik akun saat melakukan pendaftaran akun yang mana data dapat dirubah. Dan Logout untuk keluar dari sistem. Tampilan menu pada aplikasi mobile dapat dilihat pada Gambar 11.

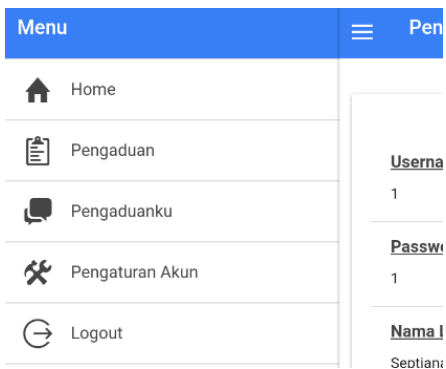

Gambar 11. Halaman menu pengaduan.

Menu home merupakan menu utama dan yang yang pertamakali ditampilkan saat berhasil login. Pada menu ini terdapat tampilan data dalam bentuk list (tab data pengumuman, tab data pemasangan, dan tab data pengaduan) dan juga tampilan data dalam bentuk peta. Untuk beralih dari tampilan list data ke peta dengan menggunakan tombol yang berada pada pojok kanan bawah tampilan. Tampilan menu home pada aplikasi mobile dapat dilihat pada Gambar 12.

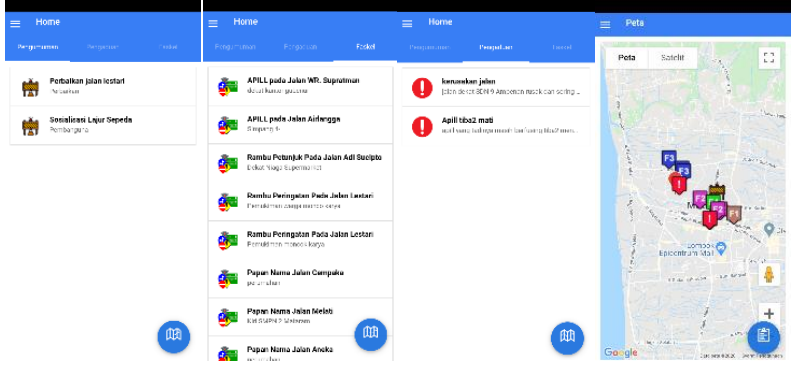

Gambar 12. Halaman menu home.

Menu pengaduan merupakan menu untuk melakukan proses pengaduan kerusakan dengan memilih kategori jalan atau fasilitas kelengkapan, kemudian akan mengarahkan ke halaman peta dan form pengaduan. Perbedaan pada kedua kategori tersebut yaitu untuk pengaduan jalan, sistem akan mengambil koordinat posisi pengguna aplikasi mobile berada kemudian pada form harus meng-input nama jalan yang diadukan. Tampilan peta dan juga form pengaduan jalan dapat dilihat pada Gambar 13.

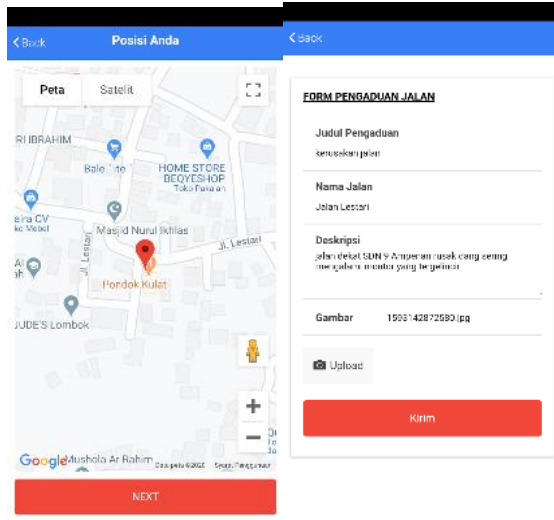

Gambar 13. Halaman pengaduan jalan.

Sedangkan untuk pengaduan fasilitas kelengkapan jalan tidak menginputkan nama jalan tapi pada peta sebelum form pengaduan, pengguna aplikasi mobile akan memilih marker fasilitas yang akan dilaporkan. Tampilan peta dan juga form pengaduan fasilitas kelengkapan jalan dapat dilihat pada Gambar 14.

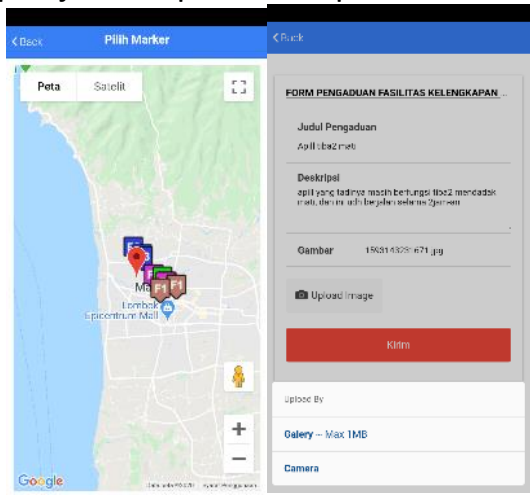

Gambar 14. Halaman pengaduan fasilitas kelengkapan jalan. 


\subsection{Pengujian sistem}

Pengujian terhadap sistem yang telah diimplementasikan bertujuan untuk mengetahui sejauh mana keberhasilan sistem dan kualitasnya. Pengujian sistem yang dilakukan yaitu pengujian black box dan pengujian kuesioner MOS.

\subsubsection{Pengujian black box}

Pengujian black box terfokus pada unit program yang memenuhi kebutuhan (requirement) yang disebutkan dalam spesifikasi. Pengujian black box dilakukan dengan menjalankan unit atau modul, yang kemudian diamati apakah hasil dari unit sesuai dengan proses yang diignikan[9]. Dalam hal ini, hasil pengujian menunjukkan bahwa semua fitur sesuai dengan harapan yang diinginkan.

\subsubsection{Pengujian kuesioner MOS}

Kuesioner adalah suatu Teknik pengumpulan informasi yang memungkinkan analisis untuk mempelajari karakteristik dari sistem. Definisi Mean Opinion Score adalah nilai skala yang telah ditetapkan pada subjek yang diteliti sebagai opini performa dari sistem transmisi[10]. Pengujian MOS dilakukan dengan cara mendemokan sistem secara langsung kepada responden, lalu kemudian responden mengisi kuesioner dengan beberapa pernyataan. Jumlah keseluhan responden dalam sistem ini ada 30 orang, yang terdiri dari 3 orang dari Dinas Pekerjaan Umum dan Penataan Ruang Kota Mataram, 3 orang dari Dinas Perhubungan Kota Mataram, serta 24 orang dari masyarakat Kota Mataram. Dari setiap peryataan yang diberikan, responden akan memberikan penilaian dengan keterangan sebagai berikut :

1. Sangat Setuju (SS).

2. Setuju(S).

3. Cukup(C).

4. Tidak Setuju (TS).

5. Sangat Tidak Setuju (STS).

Selanjutnya akan dihitung presentase penilaian yang diberikan responden di setiap pernyataan. Persamaan (1) digunakan untuk menghitung presentase nilai responsi.

$$
\text { Presentase }=\frac{J}{N} \times 100 \%
$$

dimana :

$\mathrm{J}$ : total nilai responden pada setiap pernytaan

$\mathrm{N}$ : Jumlah responden

Persamaan untuk menghitung persentase rata-rata dari setiap poin jawaban adalah Persamaan (2).
Rata-rata $=\frac{(\text { Presentase ke- }-1+\ldots+\text { Presentase ke- } n)}{n}$

Adapun dari pengujian kuesioner untuk Dinas Pekerjaan Umum dan Penataan Ruang Kota Mataram, hasil dari perhitungan rata-rata seluruh pernyataan, didapatkan nilai $0 \%$ untuk penilaian cukup, tidak setuju, dan sangat tidak setuju, sedangkan nilai untuk sangat setuju, dan setuju masing-masing bernilai $66,67 \%$ dan 33,33\%. Representasi grafik dari hasil perhitungan nilai rata-rata penilaian responden dari Dinas Pekerjaan Umum dan Penataan Ruang Kota Mataram dapat dilihat pada Gambar 15.

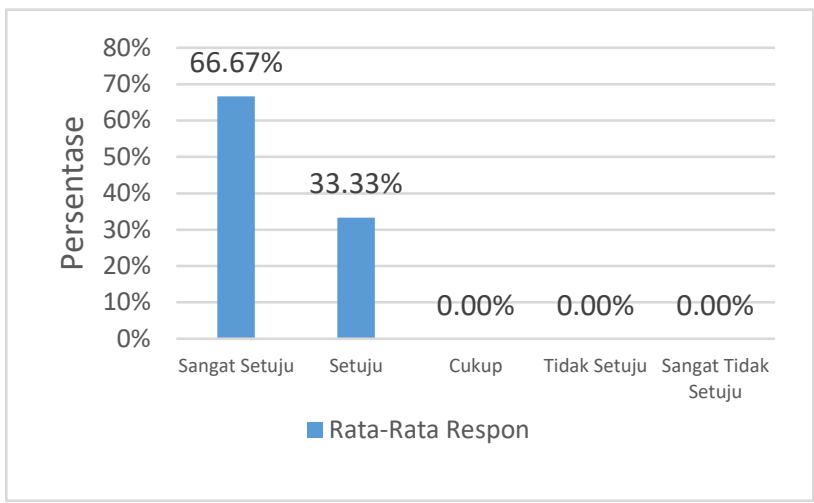

Gambar 15. rata-rata penilaian responden dari Dinas Pekerjaan Umum dam Penataan Ruang Kota Mataram.

Dari pengujian kuesioner untuk Dinas Perhubungan Kota Mataram, hasil dari perhitungan rata-rata seluruh pernyataan, didapatkan nilai $0 \%$ untuk penilaian cukup, tidak setuju, dan sangat tidak setuju, sedangkan nilai untuk sangat setuju, dan setuju masing-masing bernilai 58,33\% dan 41,67\%. Representasi grafik dari hasil perhitungan nilai ratarata penialain responden dari Dinas Perhubungan Kota Mataram dapat dilihat pada Gambar 16.

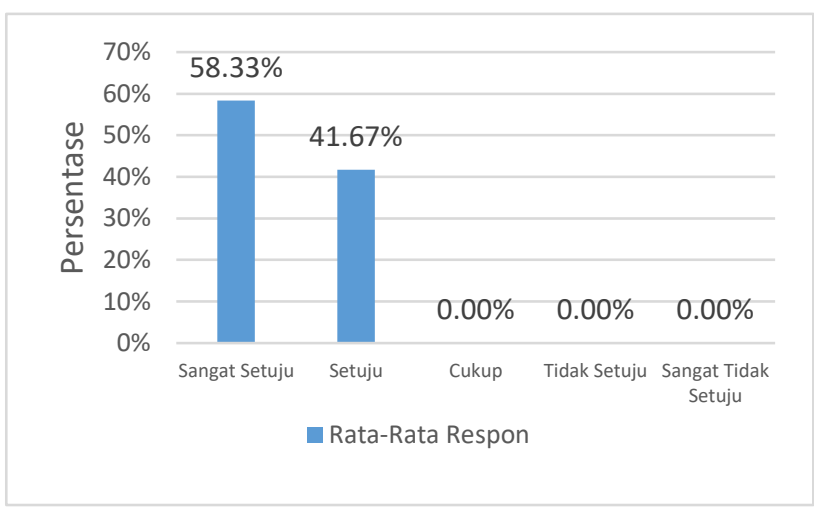

Gambar 16. Grafik rata-rata responden dari Dinas Perhubungan Kota Mataram. 
Dari pengujian kuesioner untuk masyarakat kota Mataram, hasil dari perhitungan rata-rata seluruh pernyataan, didapatkan nilai $0 \%$ untuk penilaian tidak setuju dan sangat tidak setuju, sedangkan nilai untuk sangat setuju, setuju, dan cukup masing-masing bernilai 52,50\%, 44,17\%, dan 3,33\%. Representasi grafik dari hasil perhitungan nilai rata-rata penialain responden dari masyarakat kota Mataram dapat dilihat pada Gambar 17.

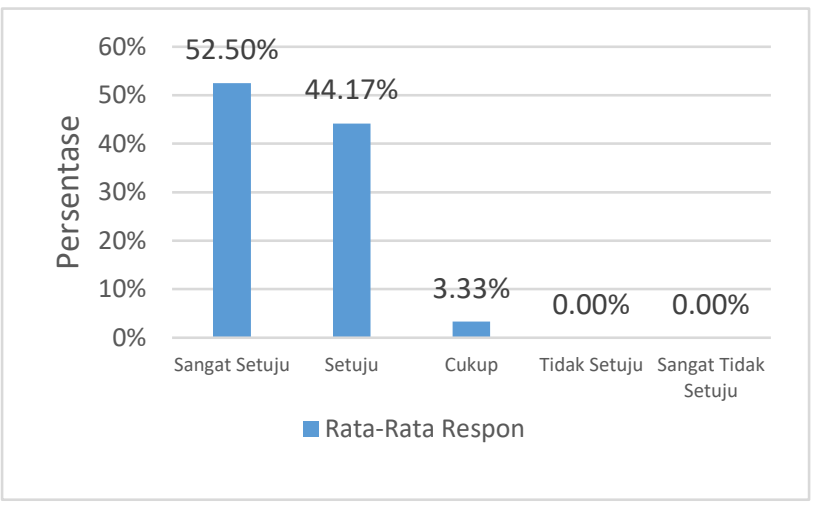

Gambar 17. Grafik rata-rata responden dari masyarakat Kota Mataram.

\section{KESIMPULAN DAN SARAN}

Berdasarkan penelitian dan pembangunan aplikasi yang dilakukan, terdapat beberapa hal yang dapat disimpulkan, antara lain:

1. Aplikasi web yang telah dibuat memudahkan mengelola data jalan dan fasilitas kelengkapan jalan, memudahkan menyampakaian informasi perabaikan/pembangunan jalan maupun fasilitas kelengkapan jalan di Kota Mataram, serta dapat menerima pengaduan kerusakan dari masyarakat.

2. Aplikasi mobile yang telah dibuat mempermudah masyarakat melihat kondisi jalan dan fasilitas kelengkapan jalan yang ada di Kota Mataram, serta dapat melakukan pengaduan kerusakan jalan dan fasilitas kelengkapan jalan kepada dinas yang bertanggung jawab.

3. Dari hasil pengujian black box yang telah dilakukan menunjukkan bahwa seluruh fungsifungsi menu pada aplikasi yang sudah dibangun sesuai dengan sistem yang diusulkan.

4. Berdasarkan hasil pengujian Mean Opinion Score (MOS) yang telah dilakukan menunjukkan bahwa rata-rata penilaian responden dari Dinas Pekerjaan Umum dan Penataan Ruang Kota Mataram terhadap aplikasi web menyatakan sangat setuju dan setuju dengan persentase masing-masing 66,67\% dan 33,33\%, sedangkan rata-rata penilaian responden dari Dinas
Perhubungan Kota Mataram terhadap aplikasi web menyatakan sangat setuju dan setuju dengan persentase masing-masing 58,33\% dan 41,67\%, dan rata-rata penilaian responden dari masyarakat terhadap aplikasi mobile menyatakan sangat setuju dan setuju dengan persentasi masing-masing $52,50 \%$ dan 44,17\%. Sehingga dapat disimpulkan bahwa sistem ini layak untuk digunakan.

Setelah merancang dan membangun Aplikasi Hybrid Kondisi Jalan dan Fasilitas Kelengkapan Jalan di Kota Mataram ini, ada beberapa saran yang akan disampaikan untuk pengembangan lebih lanjut, yaitu:

1. Untuk penelitian selanjutnya, peneliti bisa mengembangkan dengan penambahan aplikasi mobile yang dapat digunakan oleh pegawai dari dinas yang bertugas di lapangan agar memudahkan dalam pemantau dan pendataan kondisi jalan dan fasilitas kelengkapan jalan secara cepat dan langung.

2. Untuk penelitian selanjutnya, peneliti dapat menambahkan fitur untuk notifikasi data/informasi baru pada aplikasi mobile yang digunakan oleh masyarakat.

3. Untuk penelitian selanjutnya, peneliti dapat lebih meningkatkan keamanan sistem dengan menambahkan fitur untuk verifikasi sistem berdasarkan email atau dengan nomor yang dapat dihubungi sehingga dapat lebih memudahkan dalam pengamanan akun.

4. Untuk penelitian selanjutnya, peneliti dapat melakukan migrasi data atau mengevaluasi fitur untuk pengembangan sistem dan kemudian melakukan pengujian dengan metode tertentu seperti User Acceptance Test.

\section{DAFTAR PUSTAKa}

[1] Republik Indonesia, "Peraturan Menteri Pekerjaan Umum Nomor 13 Tahun 2011 tentang Tata Cara Pemeliharaan dan Penilikan Jalan", Jakarta: Menteri Pekerjaan Umum, 2011.

[2] M. G. Nastiar, "Sistem Pelaporan Kerusakan Jalan Pada Bina Marga Makassar Berbasis Web dan Mobile" Skripsi pada Program Studi Sains dan Teknologi, UIN Alauddin Makassar, Makassar, 2016.

[3] D. O. Sihombing, "Perancangan Sistem Informasi Pelaporan Masyarakat Untuk Kerusakan Jalan Di Pontianak Menggunakan Google Maps API", Jurnal Khatulistiwa Informatika, vol. 4, no. 1, 2016.

[4] A. B. A. Pramuji, "Aplikasi Crowdsourching Pelaporan Kerusakan Jalan Di Dinas Pekerjaan 
Umum dan Perumahan Sleman Berbasis Android", Skripsi pada Program Studi Sistem Informasi, Sekolah Tinggi Manajemen Informatika dan Komputer, AKAKOM, Yogyakarta, 2017.

[5] R. A. Pascapraharastyan, A. Supriyanto, dan P. Sudarmaningtyas, "Rancangan Bangun Sistem Informasi Manajemen Arsip Rumah Sakit Bedah Surabaya Berbasis Web", Jurnal Sistem Informasi, vol. 3, no. 1, 2014.

[6] A. P. Basuki, "Proyek Membangun Website Berbasis PHP dengan Codelgniter", Yogyakarta: Lokomedia, 2014.
[7] J. F. Tompoh, S. R. Sentinuwo, dan A. A. E. Sinsuw, "Rancang Bangun Aplikasi Pemesanan Menu Makanan Restoran Berbasisi Android", E-jurnal Teknik Informatika, Vol. 9, No. 1, 2016.

[8] Rosa dan M. Shalahuddin, "Rekayasa Perangkat Lunak Tersetruktur dan Berorientasi Objek", Bandung: Informatika, 2013.

[9] H. Fatta, "Analisis dan Perancangan Sistem Informasi", Yogyakarta: ANDI, 2007.

[10] G. A. Putra, Endroyono, dan G. Kusrahardjo, "Rancang Bangun Software Sistem Monitoring TV Digital DVB-T2", Jurnal Teknik ITS, vol. 4, no. 1, 2015. 